\title{
フレッシュアイズ
}

研究室のホームページアドレス

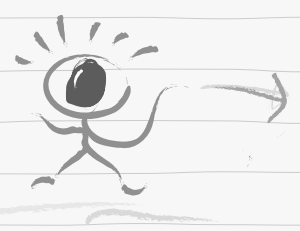

\section{東京大学 相澤・山崎研究室}

http://www.hal.k.u-tokyo.ac.jp/

†東京大学 大学院 新領域創成科学研究科 基礎情報学専攻

"Aizawa Yamasaki Laboratory, the University of Tokyo" by Koji Nakahira and Takashi Miyaki (Department of Frontier Informatics, Graduate School of Frontier Sciences, the University of Tokyo)

\section{1. 相澤・山崎研究室について}

東京大学大学院情報理工学系研究科 相澤・山崎研究室は, 現在, 主に東京 都文京区にある本郷キャンパスを拠点 に活動を進めています。また，2006 年まで新領域創成科学研究科に所属し ていたこともあり，千葉県柏市にある 柏キャンパスでも研究活動を行ってい ます。当研究室所属の石川尊之が 2005年映像情報メディア学会年次大 会での発表により学生優秀賞を受賞し たことから，このたび当研究室を紹介 することになりました．現在の研究室 の構成は, 相澤清晴教授, 山崎俊彦講 師, 宮尾秘書, リサーチフェロー1名, 博士学生5名, 修士学生8名, 卒論生6
名の23名です（図1)。研究室内のみで 活動しているだけでなく, 学内の組織 横断的なプロジェクトグループ，民間 企業, 国立研究所，NPO等とも共同で 研究を行っています.

今日，人の実質的な活動世界 (Virtual World）は，映像を軸にしたメディア技 術により拡大を続けています。次世代 の情報環境は，映像メディアを中心に 発展して行くと思われます。当研究室 では,この次世代の情報環境の構築に 必要不可欠な画像情報処理に関する研 究を行っています。映像情報をいかに 解析するか，いかに利用するかに興味 があり，㒷の分野は，画像の取得から 符号化, 処理, 出力, 応用システムま で，関連する多くの要素技術にわたつ

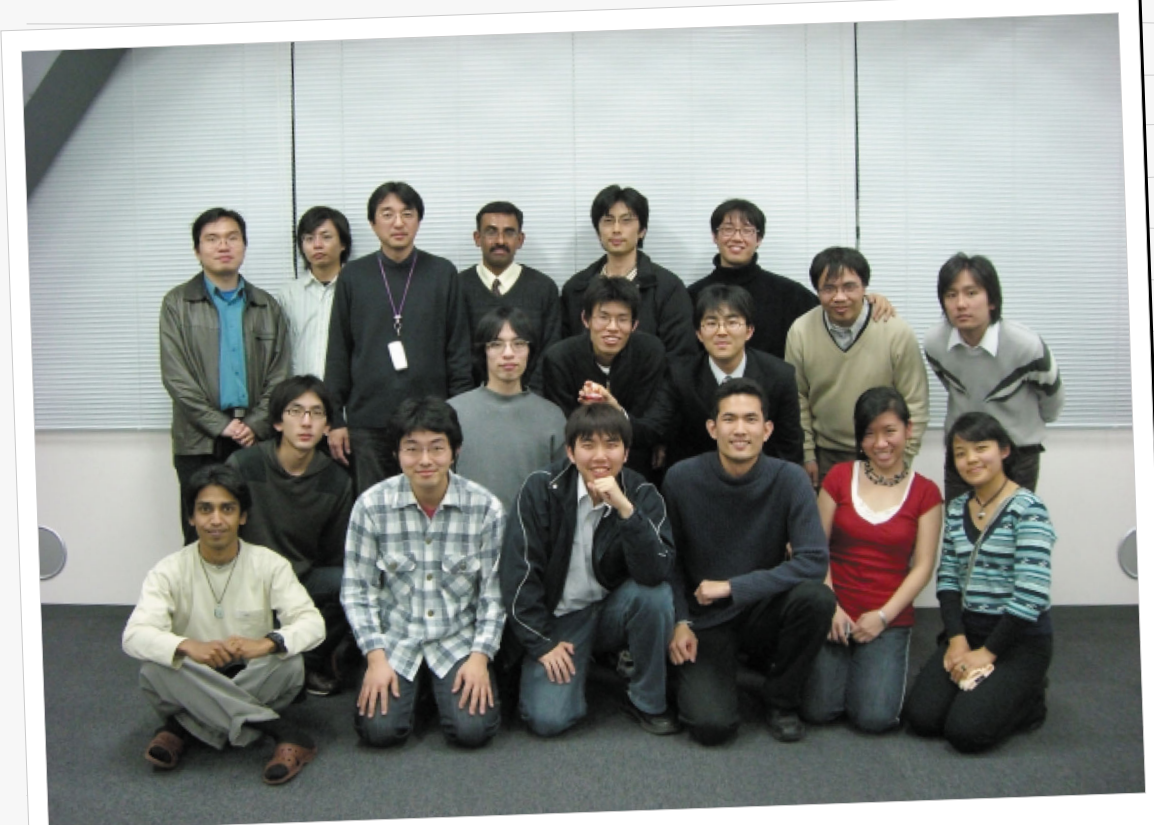

図1昨年度の研究室の様子

中平浩二十, 味八木崇

ています.したがって, 研究内容は, ウェアラブルやユビキタス環境での体 験情報処理, Webのための画像情報処 理, 3次元ビデオ処理技術と幅広いもの になっており, また, ただ単にソフト ウェアの開発を行うだけでなく, 各種 デバイスを使ったハードウェア作りも 積極的に行っています.プロセッサの 性能，記録容量など“量”が飛躍的な 進展を遂げている中で，まったく新し (映像メディア技術として何が可能な のかを模索しています。

\section{2. 研究テーマ紹介}

当研究室では大きく分けて, (1)ライ フログ・体験のマルチメディア情報処 理, (2) 広域·集団サーベイランス, (3) 3次元ビデオ処理, (4) Webの視覚情報 処理, の四つのテーマについて研究し ています，以下に兴れぞれテーマにつ いて説明します。

\section{1 ライフログ・体験のマルチメデ ィア情報処理 \\ センシングデバイスと情報処理機器} の小型化が進み, ウェアラブルあるい はユビキタスなメディアにより, 個人 の生活体験を長期間記録することが可 能になりました。 人の一生分の映像記 録も产れほど遠くない時期に可能にな るでしょう. 弚の場合, 大容量の情報 の効率的な検索, 要約が大きな課題に なることが予想されます．膨大な体験 を処理していくためには，コンテンツ (映像也音声) のみならず，コンテキス ト(種々のセンサ情報)を最大限に活用 する必要があり, 当研究室では兴のデ 一夕取得と処理に取組んでいます。

ウェアラブル機器を用いた実験シス 


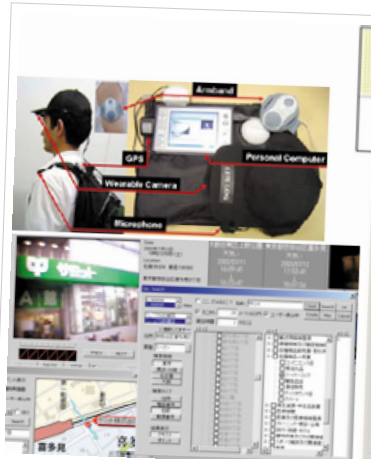

図2 ウェアラブルシステム

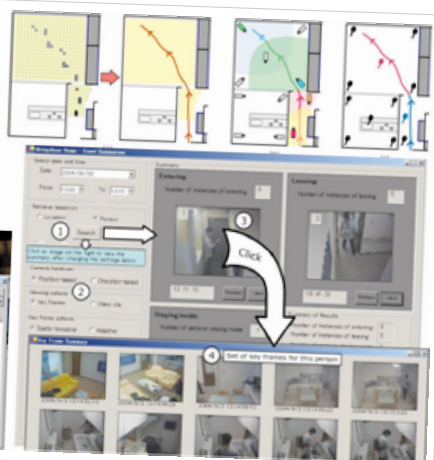

(左)，ユビキタスホーム（右）

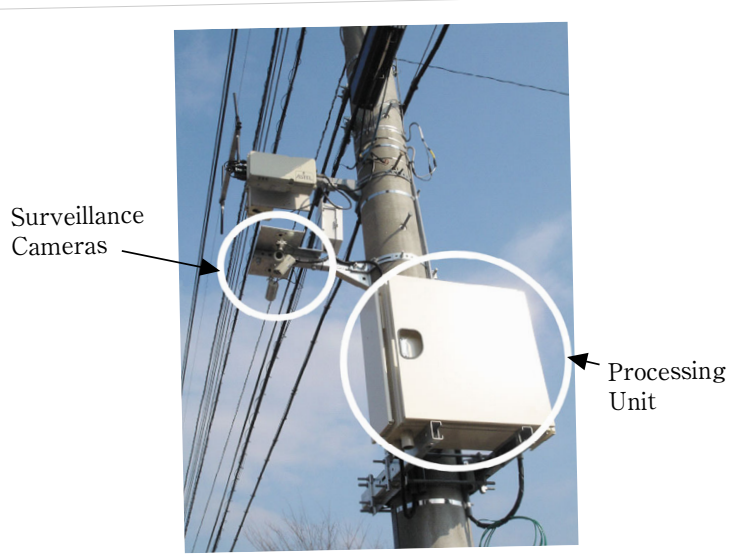

図3 電柱に敷設したサーベイランスシステム
テムでは，小型のカメラやマイクに加 え, GPSやモーションセンサ等の各種 センサを用いて日々の生活を常時記録 しています. 取得されたデータは非常 に膨大になるため, 効率的な映像の要 約化や高速な検索機能が必要になりま す、私たちの研究室では，センサ等か ら得られるコンテキスト情報と, 映 像・音声処理による会話検出などから 得られるコンテンツ情報を融合して， 効率的にデータの処理を行う研究を行 っています，記録されたライフログ映 像は, 取得された各種データを基に独 自開発したビューワーで，イベントの フレーム表示や閲覧・検索が行うこと ができます (図2).

NICT (情報通信研究機構) が構築し たユビキタスホームで行った日常記録 実験では，住居空間に設置された圧力 センサ, カメラ, マイクを利用して, 実際に生活している様子を記録し，人 のいる位置を把握した上での記録映像 の要約・閲覽，イベントの検出を行っ ています.また, 先に紹介したウェア ラブルシステムを用いて取得されるデ 一夕を融合した，協調的処理について も研究を行っています.

このほか，次のテーマに取組んでい ます。

（1）ウェアラブルによるライフログ データの取得

（2）ライフログデータの処理, イン デキシング

（3）生体情報を利用した環境移動検出

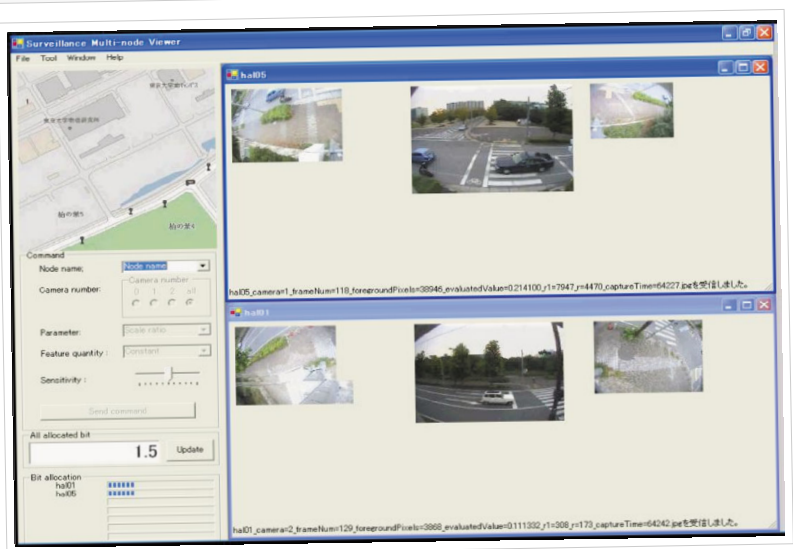

図4 多数カメラ映像の伝送, 表示

（4）ユビキタスホームデータの処理

（5）圧力センサからの追跡，ハンド オーバ

（6）コンテクストデータからの要約

（7）音響データ解析と行動分類

(8)ウェアラブル・ユビキタスセン サの統合処理

（9）画像を用いた匿名IDシステム

（10）画像による人物の行動履歴検索 システム

\section{2 広域・集団サーベイランス}

屋外の広い地域に多数のカメラ (36 台）を設置し，映像を取得・処理する 試みを始めています。NPOとともに, つくばエクスプレス・柏の葉キャンパ ス駅前から，柏キャンパス前の街路に わたる電柱に，カメラ，PC，無線 LANのアクセスポイントを敷設してお り，屋外での大規模なサーベイランス
実験を行っています（図3）。今回は映 像伝送と人物追跡の取組みについて紹 介します。

映像伝送に関しては，無線LANを多 数チャネル映像の伝送手段として用い るという厳しい制約のもとで，いかに 効率よく必要な映像を送るか，という ことが大きな課題となります。システ ム構成に基づいた階層的帯域割当てと, 監視対象となる動物体が存在する，力 メラ映像の優先的伝送を実現するため の評価尺度を導入することによって， 多数カメラ映像の伝送, 同時表示を実 現するシステムを構築しました (図4).

多数力メラによる人物追跡では，映 像による追跡を開始する初期位置の設 定や，広域をカバーするためのカメラ 間・処理ノード間での追跡対象の受け 渡しが問題となります。私たちはこの 
問題を解決するために，映像に加えて 伝送にも利用している無線LANの電波 強度測定に着目した，無線端末の位置 推定システムを併用する追跡手法を提 案し, 屋外カメラ環境上にシステムを 構築しました。

このほか，次のテーマに取組んでい ます.

(1) 屋外·広域センシングシステム の構築

(2) 無線LAN環境下での効率的な映 像伝送

（3）分散処理による広域 ·多数カメ ラにわたる人物追跡

（4）記録映像の効率的な検索

(5) 無線LANによる位置推定の統合

（6）音響情報の利用

（7）赤外線カメラを用いた夜間監視 システム

（8）同軸重畳カメラシステムを用い たサーベイランスシステムにお ける追跡処理

\subsection{3次元ビデオ処理}

2 次元映像の圧縮については, MPEGやH.264など，さまざまな標準 化手法が提案されていますが，3次元 ビデオに関しては，ほとんど手つかず のままです。少こで当研究室では，3 次元ビデオの空間的・時間的相関を明 らかにし，効率的な圧縮を行う手法に ついて開発を行っています。

実世界を動的な3次元グラフィック オブジェクトとして取込む3次元ビデ オでは，自由に視点を変えて視聴する ことができます。钅の一方, 幾何情報, テクスチャとも時間的に変化し，情報 量は膨大であり, 将来, 3次元ビデオ の利活用が進むためには，技術的な課 題が多い状態です。钅こで当研究室で は，圧縮，セグメンテーション，検 索・編集という利活用に関わる新しい 領域の研究を進めています。特に舞踊 などの人の動作を対象とした3次元ビ デオ処理の研究を進めています(図5).

例えば，セグメンテーションに関し ましては，3次元モデルと基準点との 距離のヒストグラムや，3次元オブジ ェクトを囲むバウンディングボックス の時間的変化を解析することにより，

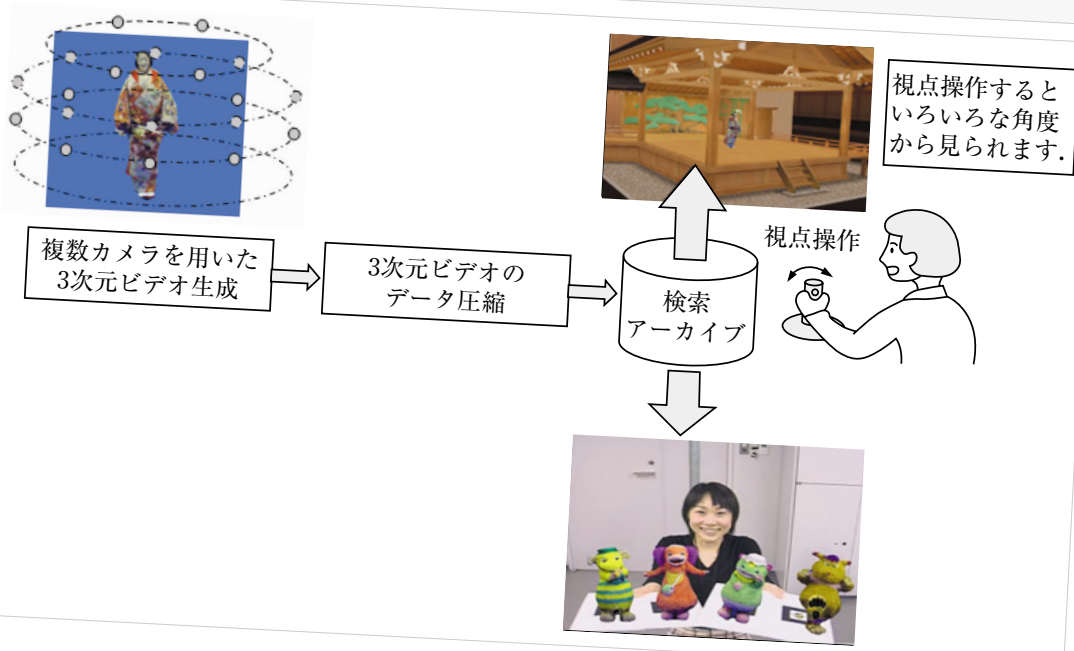

図5 3次元ビデオプロジェクトの概要

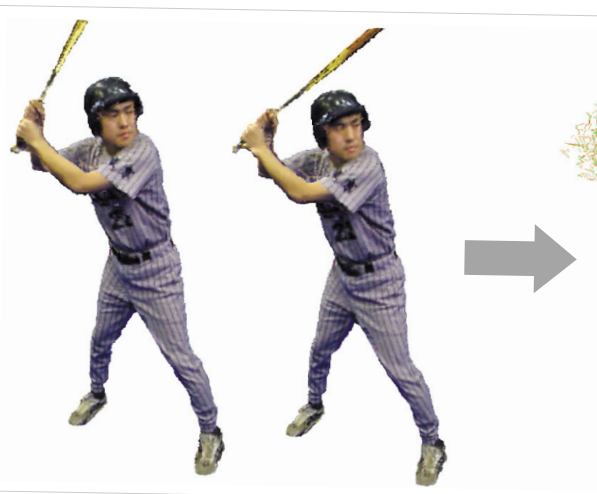

図6 3次元ビデオの圧縮

高精度なセグメンテーションを実現し ました。 また，セグメンテーションの 性能は主観的評価によって論じられる ことが多いのですが，客観的に評価す るための数学モデルも併せて検討して います。

また，3次元ビデオの圧縮に関して は, 2次元動画像圧縮で用いられるブ ロックマッチングを3次元に拡張し， 信号処理的に動的モデルを圧縮する方 式の検討を行っています。この方式で は3次元オブジェクトをさいの目状に ブロック化し，3次元の構造を保った まま隣接するフレーム内のブロックと マッチングを行っています。 兴の結果, 抽出された動きべクトルや頂点座標の 差分を, エントロピー符号化やDPCM によって圧縮しています(図6)。
一方，3次元CGも高精細化，高画質 化への道を辿っており, データ量は増 加し続けています。兴こで，3次元CG の属性データの圧縮, 数式モデル化に ついても検討を行っています。

研究トピックを以下に示します.

(1) 3次元ビデオの圧縮

(2) 3元ビデオのセグメンテーション

(3) 3次元ビデオの検索

(4) 3次元ビデオの編集

(5) 3次元ビデオのモーフィング

（6）3次元3G属性データの圧縮

（7）簡易な3次元ビデオ用取得システ 厶の構築

\subsection{Webの視覚情報処理}

今日において，Web上には非常に多 $く$ 視覚的情報で満ち溢れています. しかしながら，未だWebに対する研究 


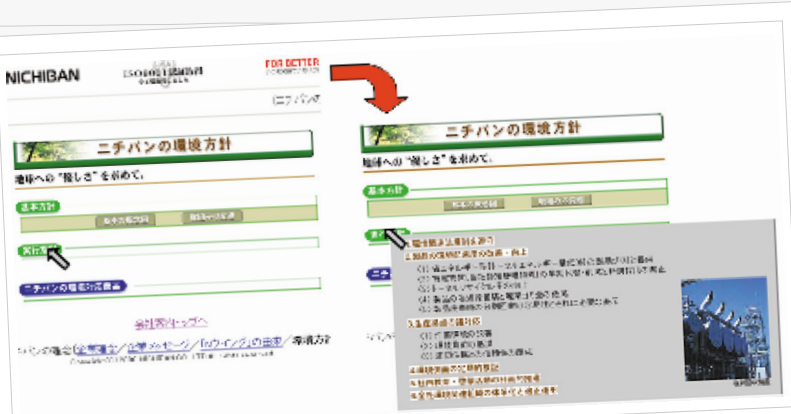

図7 Web画像の役割に基づくページ要約

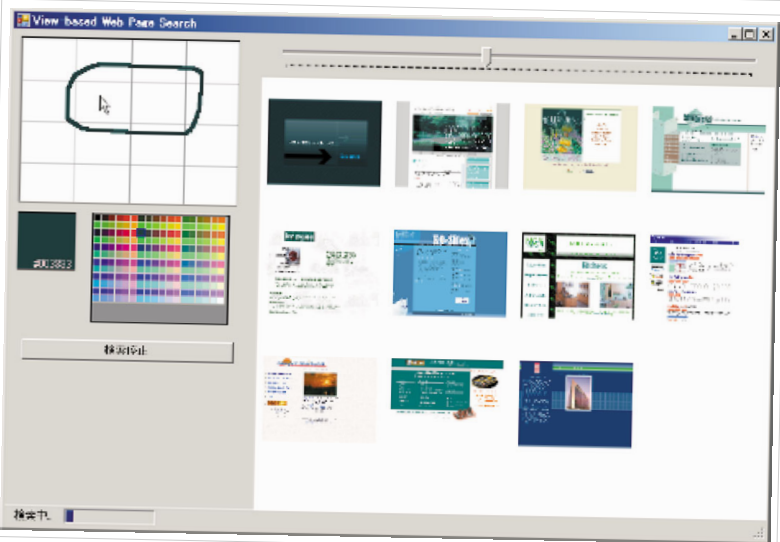

図8 見た目に基づくWeb検索システム
ではほとんどがテキスト処理によるも のです．最近GoogleやYahoo!でサー ビスが開始されたイメージサーチで も，実は周辺のテキストのみが利用さ れていて画像内容はほとんど無視され るのが現状です．Webで使われる画像 は口ゴから自然画像まで多彩な用途, 種類の画像が用いられています。我々 は，画像を中心にしたWebの情報処理 を研究しており，例えば，従来とはま ったく異なり，視覚的な観点からの， Webの分類や要約を進めています. Web画像を役割毎に分類し，炎れを利 用することで, Webページの要約など に応用しています(図7).

また，Webぺージ上の画像の利用に とどまらず, Webページ言のものをレ ンダリングされた状態で解析する手法 を検討しています。Webページの内容 兴のものや, 論理構造ではなく, Web ページの見た目をベースに解析するこ とで，現在のテキストベースの解析に 基づくWebとは異なる，新たなWebコ ンテンツの可能性を開拓することを目 指しています。 兴の一として, Web
ページを見た目の印象で検索するため のインタラクティブなシステムを構築 しました(図8).スケッチをクエリと し，簡単な色情報といくつかの矩形を 入力するだけで類似するレイアウトの Webページを検索する直感的なインタ フェースを実現しています。

研究トピックを以下に示します.

(1) Web画像要素の役割分類

(2) Webページの要約·カテゴリー 分け

（3）Web画像を用いたページ類似度 評価

（4）見た目に基づく閲覧履歴の検索 システム

(5) スケッチベースのインタラクテ イブな検索

（6）Web画像による適合性フィード バック

（7）画像に基づくフィルタリング

（8）携帯力メラを用いた画像検索

\section{3.むす び}

相澤·山崎研究室では, 画像·映像 を中心としたメディア処理について,
兴の取得から符号化, 処理, 出力, 応 用システムまで多くの要素技術を研究 対象としています。兴の中から今回は, 「ライフログ ·体験のマルチメディア 情報処理」,「広域·集団サーベイラン ス」,「3次元ビデオ処理」,「Webの視 覚情報処理」のテーマに分けて研究の 概要を紹介させて頂きました。

(2007年4月3日受付)

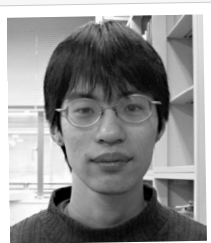

2003年, 東京大学工学部 電子工学科卒業. 2005年, 東京大学大学院新領域創 成科学研究科基盤情報学 専攻修士課程修了. 現在, 同大学大学院博士課程在 学中. 画像処理の研究に 中平 浩二 従事.

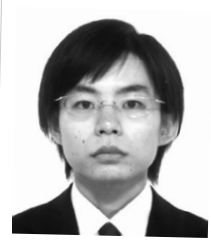

2003年, 慶應義塾大学環 境情報学部卒業. 2005年, 東京大学大学院新領域創 成科学研究科基盤情報学 専攻修士課程修了. 現在, 同大学大学院博士課程在 学中. ビデオサーベイラ ンス, 動画像処理の研究

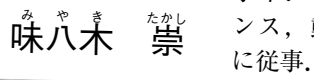

